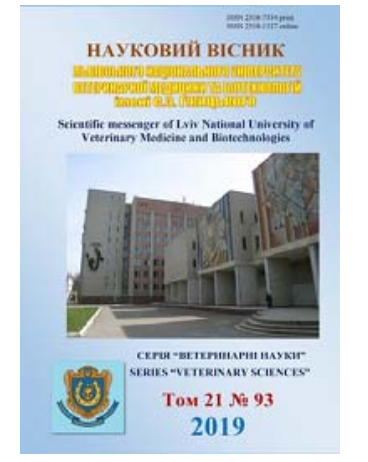

Науковий вісник Дьвівського національного університету ветеринарної медицини та біотехнологій імені С.3. Гжицького.

\author{
Серія: Ветеринарні науки
}

Scientific Messenger of Lviv National University of Veterinary Medicine and Biotechnologies. Series: Veterinary sciences

UDC 619:611.1/.8: 611.018

\title{
Pathomorphological changes of the thymus of pigs at different stages of development of clinically expressed circovirus infection type II
}

\author{
V.V. Evert \\ Article info \\ Received 06.02.2019 \\ Received in revised form \\ 12.03 .2019 \\ Accepted 13.03.2019 \\ Dnipro State Agrarian and \\ Economic University, \\ Mandrikovskaya Str., 276, \\ Dnipro, 49100, Ukraine. \\ Tel.: +38-099-545-33-31 \\ E-mail:EvertVV@i.ua
}

Dnipro State Agrarian and Economic University, Dnipro, Ukraine

\begin{abstract}
Evert, V.V. (2019). Pathomorphological changes of the thymus of pigs at different stages of development of clinically expressed circovirus infection type II. Scientific Messenger of Lviv National University of Veterinary Medicine and Biotechnologies. Series: Veterinary sciences, 21(93), 113120. doi: $10.32718 /$ nvlvet 9320
\end{abstract}

PCV2-infection of pigs plays an important role in the infectious pathology of pigs, having a significant impact on the economy of pig farms in different countries. Pathomorphological changes in the body of pigs with PCV2-infection occur moderately and in stages, as a result of the simultaneous launch of a set of mechanisms to counter the causative agent of the disease, resulting in the formation of a whole spectrum of reactive and pathological processes. The main "target" for $P C V-2$ is the immune system, and the multiplication of PCV-2 in the cells of the immune system leads to their death and development of immunodeficiency state. Thymus is the central organ of lymphocytopoiesis and imunopoiesis, in it occurs differentiation of all cellular forms of mature T-lymphocytes in the pre-T-lymphocyte stage, which migrate from the bone marrow to the bloodstream. The growth and development of the thymus, as well as the bone organs, is in direct interaction with the growth and development of the spleen, lymph nodes and is reflected in the structure of the interstitial connective tissue and lymphoid parenchyma. Purpose: determination of pathomorphological changes in the thymus of pigs at different stages of the development of clinically expressed PCV2-infection. Methods. The work was carried out in pig farms of Ukraine, with intensive technology of pig rearing, at the department of normal and pathological anatomy of agricultural animals and the Scientific and Research Center for Biosafety and Environmental Control of the Agroindustrial Complex Resources of Dnipro State Agrarian and Economic University. For pathomorphological studies, animals were selected with clinical signs of active PCV2-infection (in $1 \mathrm{ml}$ of whole blood of which contained more than $10^{7}$ copies of the PCV2 virus equivalent gene) and also piglets with positive optical density of specific antibodies (Ig $G$ and $\operatorname{Ig} M$ ) in serum blood. Pathomorphological changes were characterized by gradual exhaustion of the lymphoid parenchyma with a sharp decrease in the area of the cortical substance of the particles. Against the background of the degradation of the lymphoid parenchyma of the organ, there is a tendency to increase the relative area of the interstitial connective tissue, as well as the absolute size and number of thymic bodies, has been established.

Key words: PCV2-infection, optical density Ig G i Ig M, viral load, thymus, immunohistochemistry.

\section{Патоморфологічні зміни тимуса свиней на різних стадіях розвитку клінічно вираженої цирковірусної інфекції II типу}

\author{
В.В. Еверт
}

Дніпровський державний аграрно-економічний університет, м. Дніпро, Україна

\footnotetext{
Цирковірусна інфекиія свиней відіграє важливу роль в інфекиійній патології свиней через значний вплив на економіку свиногосподарств різних країн. Патоморфологічні зміни в організмі хворих на цирковірусну інфекиію свиней відбуваються помірно та стадійно внаслідок одночасного запуску комплексу механізмів протидії збудника хвороби, результатом чого є формування иілого спектра реактивних та патологічних проиесів. Основною “мішенню” для PCV-2 є імунна система, а розмноження збудника у
} 
клітинах імунної системи призводить до їх гибелі і розвитку імунодефіцитного стану. Тимус - центральний орган лімфоцитопоеза та імунопоеза, в ньому закінчується диференціація всіх клітинних форм зрілих Т-лімфочитів на стадї пре-Т-лімфочитів, щзо мігрують з кісткового мозку з кровотоком. Ріст і розвиток тимуса, як і кісткових органів, перебуває в прямій взаємодї з ростом $і$ розвитком селезінки, лімфатичних вузлів, щчо відображається в будові міжчасточкової сполучної тканини та лімфоїдній паренхіми, а питання патоморфологічних змін тимуса свиней на різних стадіях розвитку клінічно вираженої РСV2-інфекції потребують детального вивчення. Метою дослідження було визначення патоморфологічних змін тимуса свиней на різних стадіях розвитку клінічно вираженої PCV2-інфекції. Для патоморфологічних досліджень відбирали тварин з позитивними показниками оптичної щзільності специфічних антитіл (Ig $G$ i $\operatorname{Ig} M$ ) до цирковірусу свиней II типу в сироватці крові, а також поросят з клінічними ознаками активної PCV-2 інфекиії, у 1 мл иільної крові яких містилося понад $10^{7}$ копій геном еквівалентів РCV-2 вірусу. Шляхом анатомічного препарування відбирали тимус, фіксували в 10\% розчині нейтрального формаліну, заливали в парафін, зрізи забарвлювали гематоксиліном та еозином та азур II еозином. В парафінових зрізах також визначали наявність антигену РСV-2 (імуногістохімічне забарвлення). Автором на підставі патогістологічного та імуногістохімічного досліджень визначено патоморфологічні зміни тимуса на різних стадіях розвитку клінічно вираженої РСV2-інфекції. Встановлено, щзо у тимусі поросят на різних рівнях структурної організації спостерігаються суттєві морфофункиіональні зміни, вираженість яких має пряму залежність від стадії розвитку інфекиійного процесу. Патоморфологічні зміни характеризувались поступовим виснаженням лімфоїдної паренхіми з різким зменшенням площі кіркової речовини часточок. На тлі деградації лімфоїдної паренхіми органа встановлено тенденцію до збільшення відносної площу міжчасточкової сполучної тканини, а також абсолютних розмірів та кількості тимусних тілець.

Ключові слова: РCV2-інфекція, оптична щүільність Ig G і Ig M, вірусне навантаження, тимус, імуногістохімія.

\section{Ветуп}

Важлива роль в інфекційній патології свиней належить цирковірусній інфекції, оскільки захворювання мультифакторне та має значний вплив на рентабельність свиногосподарств різних країн (Chianini et al., 2003; Brunborg et al., 2004; Opriessnig et al., 2007).

Тяжкість захворювання i різноманіття проявів PCV2-інфекції залежить від адаптаційних можливостей організму тварин. Перехід від норми до патології, від здоров'я до хвороби проходить поступово, в міру зниження адаптаційних можливостей організму та переходу від напруження регуляторних систем до їх перенапруження i виснаження. Зниження адаптаційних можливостей організму супроводжується ростом специфічних патологічних змін, що проявляються у вигляді різноманітних клінічних ознак (Krakowka et al., 2001; Gavrilin \& Evert, 2015; Gavrilin et al., 2017).

Патоморфологічні зміни в організмі хворих на цирковірусну інфекцію свиней відбуваються помірно та стадійно внаслідок одночасного запуску комплексу механізмів протидії збудника хвороби, наслідком чого $\epsilon$ формування цілого спектра реактивних та патологічних процесів (Brunborg et al., 2004; McIntosh et al., 2009; Lopez-Rodriguez et al., 2016).

Імунна система - основна “мішень” для $P C V$-2. До органів імунної системи свиней належать кісткові органи, тимус, селезінка, лімфатичні вузли, а також дифузні та агреговані лімфатичні утвори стінок травного каналу і дихальних шляхів. Розмноження збудника у клітинах імунної системи призводить до їх загибелі та розвитку імунодефіцитного стану. Імунна система 3 нервовою та ендокринною системами виконує важливу роль у підтриманні гомеостазу організму i забезпечує його адаптацію до дії несприятливих факторів зовнішнього середовища (Krakowka et al., 2001; Goralsky et al., 2011; Nauwynck et al., 2012; Gavrilin \& Evert, 2015; Gavrilina \& Evert, 2016).

Тимус - центральний орган лімфоцитопоеза та імунопоеза, в ньому закінчується диференціація всіх клітинних форм зрілих Т-лімфоцитів на стадії пре-Тлімфоцитів, що мігрують з кісткового мозку з кровотоком. Ріст і розвиток тимуса, як і кісткових органів, перебуває в прямій взаємодії з ростом і розвитком селезінки, лімфатичних вузлів, що відображається в будові міжчасточкової сполучної тканини та лімфоїдної паренхіми, а питання патоморфологічних змін тимуса свиней на різних стадіях розвитку клінічно вираженої PCV2-інфекції у доступній науковій літературі висвітлені недостатньо та потребують детального вивчення (Baimishev et al., 2009; Doster et al., 2010; Dvorak et al., 2013; Gavrilin et al., 2017).

Meта $і$ завдання дослідження: визначення патоморфологічних змін тимуса свиней на різних стадіях розвитку клінічно вираженої $P C V 2$-інфекції.

\section{Матеріал і методи досліджень}

Робота виконувалась у свинарських господарствах України 3 інтенсивною технологією вирощування свиней, на кафедрі нормальної і патологічної анатомії с.-г. тварин і науково-дослідному центрі біобезпеки та екологічного контролю ресурсів АПК Дніпровського ДАЕУ.

Для патоморфологічних досліджень відбирали тварин з позитивними показниками оптичної щільності специфічних антитіл ( $\operatorname{Ig} G$ і $\operatorname{Ig} M)$ до цирковірусу свиней II типу в сироватці крові, а також поросят 3 клінічними ознаками активної $P C V$-2 інфекції, у 1 мл цільної крові яких містилося понад $10^{7}$ копій геном еквівалентів PCV-2 вірусу (Opriessnig et al., 2007). Стадію розвитку $P C V$-2 інфекції визначали шляхом порівняння діагностичних (позитивних) значень оптичної щільності $\operatorname{Ig} G$ і $\operatorname{Ig} M$ методом ІФА-аналізу 3 використанням тест-систем Ingezim Circovirus $\operatorname{Ig}$ G/Ig M 11 PCV k2 (Ingenasa, Іспанія). За результатами ІФА-аналізу виділено 3 групи тварин: 1 - рання активна (або підгостра) інфекція перші $\operatorname{Ig} M \geq \operatorname{Ig} G$; 2 - активна (хронічна) інфекція $\operatorname{Ig} M<\operatorname{Ig} G ; 3$ - пізня інфекція (стадія розрішення) - відсутність $\operatorname{Ig} M$ на тлі високих показників $\operatorname{Ig} G .3$ кожної групи проводили забій 6 голів поросят методом гострого знекровлення. Шляхом анатомічного препарування відбирали тимус, фіксували в 10\% водному розчині нейтрального формаліну, зневоднювали і заливали в парафін (гістопласт), зрізи забарвлювали гематоксиліном та еозином 
та азур II еозином за загальноприйнятими методиками (Goralsky et al., 2011). В парафінових зрізах також визначали наявність антигену $P C V$-2 (імуногістохімічне забарвлення) (Gavrilina \& Evert, 2016).

У тимусі методом крапкового підрахунку визначали відносну площу міжчасточкової сполучної тканини та лімфоїдної паренхіми, а також відносну площу кіркової та мозкової зон часточок. Для цього проводили диференційований підрахунок крапок, які потрапили на відповідну складову гістопрепарату, не менше ніж на п'яти зрізах отриманих з кожного фрагменту, за формулою S відн $=$ Рт : Рз $\cdot 100 \%$, де $\mathrm{S}$ відн - відносна площа відповідних компонентів, \%; Рт кількість крапок, що потрапили на відповідні тканинні компоненти; Рз - загальна кількість крапок, що потрапили на всю площу гістопрепарату.

В лімфоїдній паренхімі тимуса визначали відсоткове співвідношення між окремими клітинами (великі, середні, малі лімфоцити, плазматичні та ретикулярні клітини), макрофаги та інші клітини. Підрахунок клітин паренхіми проводили на препаратах, забарвлених азур II еозином при збільшенні 10 х 100 під імерсією із розрахунку на кожні 100 клітин на десяти препаратах у 20 полях зору по кожній окремій групі тварин. На основі одержаних даних визначали середній відсотковий вміст кожного виду клітин.

Цифрові показники результатів досліджень обробляли варіаційно статистичними методами на персональному комп'ютері за допомогою комп'ютерної програми “Excel” з пакетом “Microsoft Office 2010”. Гістологічні препарати проглядали за допомогою світлового мікроскопа Olympus CX, а мікрофотографуння здійснювали з використанням відеокамери мікроскопа системи Leica DM 1000.

\section{Результати та їх обговорення}

Тимус $є$ центральним органом імунного захисту ссавців і птиці. У ньому відбувається антигеннезалежна проліферація і диференціація Т-лімфоцитів та ендокринна функція, що полягає у вироблені біологічноактивних речовин (тирозин, тимуліт, тимопоетин).

У поросят тимус $є$ сформованим паренхіматозним органом, який анатомічно поділений на шийну та грудну частки, шийна частка своєю чергою розділена на парну та непарну ділянки.

У тимусі поросят 3 клінічно вираженою PCV2інфекцією виявляли ознаки його поступової активної інволюції, що проявлялося на усіх рівнях структурної організації. На органному рівні - зменшенням абсолютних показників маси органа та довжини його окремих часток, на тканинному - поступовим зменшенням об'єму лімфоїдної тканини, переважно за рахунок кіркової зони часточок із одночасним збільшенням строми та кількості й діаметра тимусних тілець, на клітинному - зниженням загального вмісту лімфоцитів і їх окремих популяцій на тлі збільшення відносної кількості епітеліоретикулоцитів. Інтенсивність цих змін прямо залежала від стадії розвитку PCV2-інфекції.

У поросят за ранньої активної форми PCV2інфекції (підгостра стадія) абсолютна маса тимуса складала 9,75 $\pm 0,36$ г, а відносна маса 0,05 $\pm 0,001 \%$. За активної форми PCV2-інфекції (хронічна стадія) абсолютна маса тимуса значно знижувалась до 6,37 \pm 0,45 г, відносна - до $0,04 \pm 0,003 \%$, а за пізньої форми PCV2-інфекції (стадії розрішення) абсолютна не перевищує $3,97 \pm 0,13$ г, відносна $-0,03 \pm 0,001 \%$ (табл. 1).

\section{Таблиця 1}

Органометричні показники тимуса поросят на різних стадіях розвитку клінічно вираженої $P C V 2$-інфекції, $(\mathrm{M} \pm \mathrm{m}, \mathrm{n}=6)$

\begin{tabular}{|c|c|c|c|}
\hline \multirow{2}{*}{ Морфометричні показники } & \multicolumn{3}{|c|}{ Форми PCV2-інфекції } \\
\hline & Рання активна (підгостра) & Активна (хронічна) & Пізня (розрішення) \\
\hline Абсолютна маса, г & $9,75 \pm 0,36$ & $6,37 \pm 0,45 * * *$ & $3,97 \pm 0,13 * * *$ \\
\hline Відносна маса, \% & $0,05 \pm 0,001$ & $0,04 \pm 0,003 * *$ & $0,03 \pm 0,001 * *$ \\
\hline довжина шийної парної частки, мм & $64,31 \pm 8,47$ & $42,43 \pm 3,69 *$ & $27,48 \pm 1,25 * * *$ \\
\hline довжина шийної непарної частки, мм & $60,02 \pm 5,78$ & $38,92 \pm 4,52 * *$ & $25,06 \pm 1,23 * *$ \\
\hline довжина грудної частки, мм & $26,38 \pm 2,86$ & $16,37 \pm 1,33 * *$ & $11,12 \pm 1,27 * *$ \\
\hline
\end{tabular}

Примітка: *-P $\leq 0,05, * *-\mathrm{P} \leq 0,01, * * *-\mathrm{P} \leq 0,001$ порівняно $з$ попередньою стадією інфекції

Зменшення абсолютної маси органа супроводжується зменшенням його лінійних промірів. Так, довжина шийної парної частки тимуса за ранньої активної форми PCV2-інфекції сягала 64,31 $\pm 8,47$ мм, шийної непарної - 60,02 \pm 5,78 мм, а грудної 26,38 \pm 2,86 мм. При активній формі PCV2-інфекції ці показники знижувались, довжина шийної парної частки до $42,43 \pm 3,69$ мм, шийної непарної частки - до 38,92 \pm 4,52 мм, грудної частки - до $16,37 \pm 1,33$ мм. На стадії розрішення PCV2-інфекції ці показники досягали мінімуму, так, довжина шийної парної частки не перевищує $27,48 \pm 1,25$ мм, шийної непарної 25,06 \pm 1,23 мм, а грудної - 11,12 $\pm 1,27$ мм.
На тканинному рівні структурної організації тимуса поросят за клінічно виражених форм PCV2-інфекції спостерігали значні зміни співвідношення лімфоїдної та сполучної тканини. Так, кількість лімфоїдної тканини 3 розвитком інфекційного процесу поступово зменшувались, а сполучнотканинної строми - зростали.

Незалежно від стадії розвитку інфекційного процесу PCV2-інфекції основним тканинним компонентом тимуса залишалась лімфоїдна тканина, іiі загальна відносна площа варіювала в межах $87-51 \%$ (табл. 2). За підгострої стадії PCV2-інфекції відносна площа лімфоїдної тканини була максимальною, досягаючи у 
грудній частці $86,46 \pm 4,16 \%$, у шийній непарній $82,63 \pm 4,97 \%$, у шийній парній $-81,16 \pm 4,85 \%$. За активної форми PCV2-інфекції даний показник суттєво зменшувався і у грудній частці складав 71,94 \pm $5,15 \%$, у шийній непарній $-71,12 \pm 6,32 \%$, у шийній парній $-70,43 \pm 6,34 \%$. У стадії розрішення PCV2інфекції цей показник продовжував зменшуватися. Так, у грудній частці відносна площа лімфоїдної тканини не перевищувала 53,01 $\pm 2,35 \%$, у шийній непарній частці - 52,16 $\pm 5,24 \%$, у шийній парній частці $51,28 \pm 3,26 \%$.

Відповідно відносна площа сполучнотканинної строми (капсули і міжчасточкових сполучнотканинних перетинок із адипоцитами) із розвитком клінічно вираженої PCV2-інфекції зростає. Так, за ранньої активної клінічної форми PCV2-інфекції іiі відносна площа у грудній частці залишається найнижчою $(13,54 \pm 1,12 \%)$, у шийній непарній і парній дещо вища $(17,37 \pm 2,14$ і $18,84 \pm 0,96 \%$ відповідно). За активної клінічної форми $P C V 2$-інфекції відносна площа сполучнотканинної строми суттєво зростає, максимально у шийній парній частці до 29,57 $3,17 \%$, шийній непарній - до $28,88 \pm 3,77 \%$, а у грудній - до 23,06 $\pm 2,38 \%$. На стадії розрішення PCV2інфекції даний показник досягає майже 50\% загальної площі органу, у грудній частці 46,99 $\pm 3,65 \%$, у шийній непарній $-47,84 \pm 5,14 \%$, у шийній парній частці $-48,72 \pm 4,57 \%$.

У часточках тимуса поросят, незважаючи на стадію перебігу PCV2-інфекції, розподіл на кіркову та мозкову зони залишається добре вираженим.

\section{Таблиця 2}

Відносна площа тканинних компонентів тимуса поросят на різних стадіях розвитку клінічно вираженої $P C V 2-$ інфекції, $(\mathrm{M} \pm \mathrm{m}, \mathrm{n}=6)$

\begin{tabular}{|c|c|c|c|}
\hline \multirow{2}{*}{ Показники } & \multicolumn{3}{|c|}{ Форми PCV2-інфекції } \\
\hline & Рання активна (підгостра) & Активна (хронічна) & Пізня (розрішення) \\
\hline \multicolumn{4}{|c|}{ иийна парна частка } \\
\hline Лімфоїдна тканина, \% & $81,16 \pm 4,85$ & $70,43 \pm 6,34^{*}$ & $51,28 \pm 3,26^{* *}$ \\
\hline кіркова зона, \% & $56,02 \pm 3,12$ & $37,31 \pm 2,45^{* * *}$ & $25,24 \pm 6,33$ \\
\hline мозкова зона, \% & $25,14 \pm 1,24$ & $32,62 \pm 3,44 *$ & $26,04 \pm 1,85$ \\
\hline Співвідношення кіркової/мозкової зони & $1: 2,23$ & $1: 1,16$ & $1: 0,96$ \\
\hline Сполучнотканинна строма, \% & $18,84 \pm 0,96$ & $29,57 \pm 3,17 * *$ & $48,72 \pm 4,57^{* *}$ \\
\hline $\begin{array}{l}\text { Середня кількість тілець Гасаля на одну } \\
\text { часточку }\end{array}$ & $1,90 \pm 0,02$ & $2,4 \pm 0,05 * * *$ & $3,6 \pm 0,03 * * *$ \\
\hline Середній діаметр тілець Гасаля, мкм & $23,14 \pm 2,14$ & $27,01 \pm 2,55$ & $27,48 \pm 3,64$ \\
\hline \multicolumn{4}{|c|}{ шийна непарна частка } \\
\hline Лімфоїдна тканина, \% & $82,63 \pm 4,97$ & $71,12 \pm 6,32$ & $52,16 \pm 5,24 *$ \\
\hline кіркова зона, \% & $59,04 \pm 6,42$ & $38,49 \pm 3,64 * *$ & $27,03 \pm 2,51 * *$ \\
\hline мозкова зона, \% & $23,59 \pm 3,65$ & $32,63 \pm 4,58$ & $25,13 \pm 2,13$ \\
\hline Співвідношення кіркової/мозкової зони & $1: 2,50$ & $1: 1,18$ & $1: 1,07$ \\
\hline Сполучнотканинна строма, \% & $17,37 \pm 2,14$ & $28,88 \pm 3,77 * *$ & $47,84 \pm 5,14 * *$ \\
\hline $\begin{array}{l}\text { Середня кількість тілець Гасаля на одну } \\
\text { часточку }\end{array}$ & $1,6 \pm 0,04$ & $2,1 \pm 0,03 * * *$ & $3,2 \pm 0,03 * * *$ \\
\hline Середній діаметр тілець Гасаля, мкм & $24,11 \pm 3,24$ & $28,34 \pm 1,28$ & $30,41 \pm 3,67$ \\
\hline \multicolumn{4}{|c|}{ грудна частка } \\
\hline Лімфоїдна тканина, \% & $86,46 \pm 4,16$ & $71,94 \pm 5,15^{*}$ & $53,01 \pm 2,35 * * *$ \\
\hline кіркова зона, \% & $60,05 \pm 3,42$ & $39,26 \pm 2,84 * * *$ & $27,19 \pm 2,38 * * *$ \\
\hline мозкова зона, \% & $26,41 \pm 2,28$ & $32,68 \pm 3,72$ & $25,82 \pm 2,26$ \\
\hline Співвідношення кіркової/мозкової зони & $1: 2,27$ & $1: 1,20$ & $1: 1,05$ \\
\hline Сполучнотканинна строма, \% & $13,54 \pm 1,12$ & $23,06 \pm 2,38^{* *}$ & $46,99 \pm 3,65^{* * *}$ \\
\hline $\begin{array}{l}\text { Середня кількість тілець Гасаля на одну } \\
\text { часточку }\end{array}$ & $1,5 \pm 0,01$ & $2,0 \pm 0,02 * * *$ & $3,1 \pm 0,02 * * *$ \\
\hline Середній діаметр тілець Гасаля, мкм & $23,49 \pm 2,24$ & $30,46 \pm 4,26$ & $33,17 \pm 3,74$ \\
\hline
\end{tabular}

Примітка: $*$ - $\mathrm{P} \leq 0,05, * *-\mathrm{P} \leq 0,01, * * *-\mathrm{P} \leq 0,001$ порівняно з попередньою стадією інфекції

Відомо, що відносна площа кіркової зони часточок тимусу є показником функціональної активності даного органу. Виявлені показники у тимусі поросят вказують на поступове зниження його функціональної активності 3 розвитком стадій клінічно вираженої PCV2-інфекції.

Для ранньої активної клінічної форми PCV2інфекції відносна площа кіркової зони часточок тиму- са залишається високою, досягаючи у грудній частці $60,05 \pm 3,42 \%$, у шийній непарній - 59,04 $\pm 6,42 \%$, а у шийній парній $-56,02 \pm 3,12 \%$ (рис. 1a). За активної форми $P C V 2$-інфекції даний показник різко знижується до $39,26 \pm 2,84 \%$ у грудній частці, до $38,49 \pm 3,64 \%$ у шийній непарній та до $37,31 \pm 2,45 \%$ у шийній парній частці (рис. 1б). 

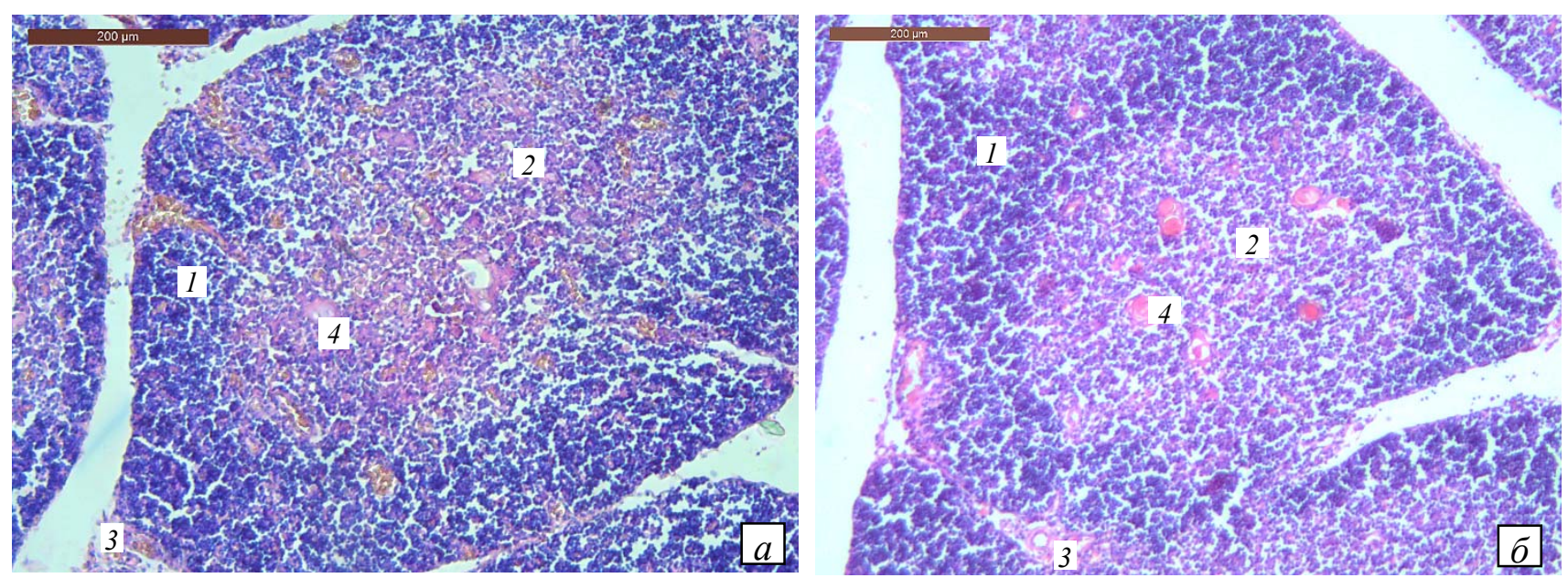

Рис. 1. Гістологічний препарат грудної частки тимуса поросяти за ранньої активної (а) та активної (б) клінічно вираженої PCV2-інфекції: 1 - кіркова речовина часточок; 2 - мозкова речовина часточок; 3 - міжчасточкова сполучна тканина; 4 - тільця Гасаля. Гематоксилін та еозин. $\times 100$

Ще більшим зниженням відносної площі кіркової зони часточок тимуса характеризується пізня клінічна форма PCV2-інфекції. У грудній частці тимуса іiі відносна площа не перевищує $27,19 \pm 2,38 \%$, у шийній непарні - 27,03 $\pm 2,51 \%$, а у шийній парній $-25,24 \pm$ $6,33 \%$.

Відносна площа мозкової зони часточок тимуса 3 розвитком $P C V 2$-інфекції відповідно збільшується. За ранньої активної форми $P C V 2$-інфекції у шийній непарній частці тимуса даний показник $є$ мінімальним $(23,59 \pm 3,65 \%)$, у шийній парній і грудній незначно вищим $(25,14 \pm 1,24$ і 26,41 $\pm 2,28 \%$ відповідно).

Активна форма $P C V 2$-інфекції характеризувалась різким збільшенням даного показника часточок тимуса поросят. Відносна площа мозкової зони часточок тимуса досягала максимальних значень за весь період досліджень і виявилася майже однаковою в усіх частках тимуса (близько 33\%).

На стадії розрішення PCV2-інфекції відносна площа часточок тимуса поросят знижувалась, даний показник не перевищує $25,13 \pm 2,13 \%$ у шийній непарній частці, $25,82 \pm 2,26 \%$ у грудній частці та 26,04 \pm $1,85 \%$ у шийній парній частці.

Відповідно співвідношення кіркової і мозкової зон часточок залишався найвищим у тимусі поросят за ранньої активної форми $P C V 2$-інфекції: у шийній непарній $-1: 2,50$; у грудній - $1: 2,27$; у шийній парній $-1: 2,23$. Значно знизилося співвідношення за хронічної стадії інфекції: у грудній до $1: 1,20$, у шийній непарній до $1: 1,18$, у шийній парній до $1: 1,16$. Для стадії розрішення PCV2-інфекції характерний найнижчий показник співвідношення кіркової і мозкової зон часточок тимуса поросят. У грудній частці співвідношення становить $1: 1,05$, у шийній непарній 1 : 1,07, а в шийній парній відносна площа кіркової зони часточок є меншою за мозкову, співвідношення становить відповідно $1: 0,96$.

Відомо, що кількість і розміри тимусних тілець (Гасаля) $є$ показником функціональної активності органа. Зростання їхньої кількості та абсолютних розмірів може вказувати на попереднє напруження роботи тимуса і поступову деградацію епітеліоретикулярного остову паренхіми часточок, що безпосередньо здійснюють регуляцію антигеннезалежної диференціації і проліферації Т-лімфоцитів та їх позитивну і негативну селекцію.

Встановлено, що за ранньої активної форми PCV2інфекції середня кількість тимусних тілець на одну часточку була мінімальною і не перевищувала $1,5 \pm$ 0,01 у грудній частці, $1,6 \pm 0,04$ у шийній непарній та $1,9 \pm 0,02$ у шийній парній частці тимуса. Для даної стадії PCV2-інфекції також характерні мінімальні значення і їх середнього діаметру: у грудній частці $23,49 \pm 2,24$ мкм, у шийній непарній $-24,11 \pm$ 3,24 мкм, у шийній парній - 23,14 мкм.

3 розвитком інфекційного процесу дані показники суттєво зростають. Так, за активної форми PCV2інфекції середня кількість тимусних тілець на одну часточку в грудній частці тимуса збільшувалась до $2,0 \pm 0,02$, у шийній непарній до $2,1 \pm 0,03$, а у шийній парній до 2,4 $\pm 0,05$. Середній діаметр тимусних тілець у грудній частці тимуса складав 30,46 4,26 мкм, у шийній непарній $-28,34 \pm 1,28$ мкм, у шийній парній $-27,01 \pm 2,55$ мкм. Для стадії розрішення $P C V 2$-інфекції характерні максимальні показники як кількості, так і абсолютних розмірів тимусних тілець часточок тимуса. При цьому тимусні тільця розташовані й дифузно, і у вигляді невеликих скупчень.

Найбільша кількість тимусних тілець виявлена у шийній парній частці тимуса $3,6 \pm 0,03$, проте вони мали найменший діаметр - лише 27,48 $\pm 3,64$ мкм. У шийній непарній частці середня кількість тимусних тілець на одну часточку склала $3,2 \pm 0,03$, їх середній діаметр не перевищував 30,41 $\pm 3,67$ мкм, дещо менша кількість тимусних тілець виявлена у грудній частці - 3,1 $\pm 0,02$, проте вони мали найбільший діаметр $-33,17 \pm 3,74$.

На клітинному рівні структурної організації часточок тимуса поросят за клінічно вираженої PCV2інфекції виявляли значні зміни у співвідношенні клітинних елементів. 3 розвитком $P C V 2$-інфекції залеж- 
но від стадії загальна кількість лімфоцитів зменшувалася як у кірковій, так і у мозковій зоні часточок тимуса, тимчасом як відносна кількість епітелоретикулоцитів і макрофагів зростала (табл. 3). Також серед лімфоїдних клітин ми практично не виявляли клітини
3 фігурами мітозу. Значна частина лімфоцитів підлягала некрозу, їх ядра були у стані рексису, пікнозу та навіть лізису, що найбільше проявлялося на стадії розрішення PCV2-інфекції.

Таблиця 3

Динаміка відносної кількості клітин кіркової та мозкової зони тимуса на різних стадіях розвитку клінічно вираженої $P C V 2$-інфекції, $(\mathrm{M} \pm \mathrm{m}, \mathrm{n}=6)$

\begin{tabular}{|c|c|c|}
\hline \multirow{2}{*}{ Клітинні компоненти } & \multicolumn{2}{|c|}{ Зони тимуса } \\
\hline & Кіркова & Мозкова \\
\hline \multicolumn{3}{|c|}{ Рання активна форма (підгостра стадія) РСV2-інфекиії } \\
\hline Імунобласти і великі лімфоцити & $2,16 \pm 0,12$ & $0,97 \pm 0,02$ \\
\hline Середні лімфоцити & $8,17 \pm 1,25$ & $5,48 \pm 0,63$ \\
\hline Малі лімфоцити & $70,13 \pm 6,13$ & $63,14 \pm 3,17$ \\
\hline Макрофаги & $4,61 \pm 0,11$ & $4,16 \pm 0,10$ \\
\hline Епітеліоретикулоцити & $12,41 \pm 0,82$ & $19,14 \pm 1,26$ \\
\hline Інші клітини ${ }^{1}$ & $2,52 \pm 0,01$ & $7,11 \pm 0,42$ \\
\hline \multicolumn{3}{|c|}{ Активна форма (хронічна стадія) РCV2-інфекиії } \\
\hline Імунобласти і великі лімфоцити & $1,83 \pm 0,12^{*}$ & $0,72 \pm 0,03 * * *$ \\
\hline Середні лімфоцити & $7,16 \pm 1,23$ & $3,97 \pm 0,24 *$ \\
\hline Малі лімфоцити & $60,01 \pm 5,12$ & $52,94 \pm 5,34$ \\
\hline Макрофаги & $8,15 \pm 0,32 * * *$ & $7,63 \pm 0,17 * * *$ \\
\hline Епітеліоретикулоцити & $14,08 \pm 1,72$ & $26,01 \pm 2,34 * *$ \\
\hline Інші клітини 1 & $6,94 \pm 0,27 * * *$ & $8,73 \pm 0,63 *$ \\
\hline \multicolumn{3}{|c|}{ Пізня форма (стадія розрішення) РCV2-інфекції } \\
\hline Імунобласти і великі лімфоцити & $0,52 \pm 0,02 * * *$ & $0,31 \pm 0,01 * * *$ \\
\hline Середні лімфоцити & $3,68 \pm 0,43 * *$ & $2,93 \pm 0,52$ \\
\hline Малі лімфоцити & $49,14 \pm 4,25$ & $39,62 \pm 3,64 *$ \\
\hline Макрофаги & $17,06 \pm 0,78 * * *$ & $19,27 \pm 1,46^{* * *}$ \\
\hline Епітеліоретикулоцити & $24,02 \pm 1,57 * * *$ & $30,08 \pm 3,65$ \\
\hline Інші клітини 1 & $5,58 \pm 0,57 *$ & $7,79 \pm 0,68$ \\
\hline
\end{tabular}

Примітка: ${ }^{*}-\mathrm{P} \leq 0,05,{ }^{*}-\mathrm{P} \leq 0,01,{ }^{* * *}-\mathrm{P} \leq 0,001$ порівняно 3 попередньою стадією інфекції; ${ }^{1}-$ нейтрофільні, еозинофільні гранулоцити, еритроцити

За ранньої активної форми PCV2-інфекції (підгостра стадія) загальна кількість лімфоїдних клітин у часточках тимуса залишається достатньо високою, проте нижчою, ніж за латентної та субклінічної форми. У кірковій зоні часточок тимуса поросят за ранньої активної формі PCV2-інфекції загальна кількість лімфоцитів складає близько $80 \%$, а у мозковій - майже 70\%. Із них найбільша кількість припадає на малі лімфоцити, відносна кількість яких у кірковій зоні сягає 70,13 $\pm 6,13 \%$, а у мозковій зоні $-63,14 \pm 3,17 \%$. Значно менша кількість припадає на середні лімфоцити - лише $8,17 \pm 1,25 \%$ у кірковій зоні, $5,48 \pm 0,63 \%$ у мозковій та імунобласти і великі лімфоцити у кірковій не перевищує $2,16 \pm 0,12 \%$, у мозковій $-0,97 \pm 0,02 \%$.

За активної форми PCV2-інфекції (хронічна стадія) загальна кількість лімфоцитів часточок тимуса поросят різко зменшується. Тут відносна кількість лімфоцитів знижується в кірковій і у мозковій зонах майже на $10 \%$ порівняно із ранньою активною $P C V 2$ інфекцією (підгострою стадією). Зменшення відносної кількості лімфоїдних клітин відбувається переважно за рахунок малих лімфоцитів, їх відносна кількість у кірковій зоні часточок тимуса складає $60,01 \pm 5,12 \%$, у мозковій зоні $-52,94 \pm 5,34 \%$. Відносна кількість середніх лімфоцитів, імунобластів і великих лімфоцитів також знижується. Відносна кількість середніх лімфоцитів у кірковій зоні часточок складає 7,16 $1,23 \%$, а у мозковій $-3,94 \pm 0,24 \%$, імунобластів і великих лімфоцитів у кірковій зоні $-1,83 \pm 0,12 \%$, у мозковій $-0,72 \pm 0,03 \%$.

Для пізньої форми PCV2-інфекції (стадія розрішення) тенденція до зменшення загальної кількості лімфоїдних клітин у часточках тимуса зберігається. Так, у кірковій зоні часточок тимуса загальна відносна кількість лімфоцитів не перевищує 54\% у мозковій 43\%. Відносна кількість окремих популяцій лімфоцитів також знижується. Кількість малих лімфоцитів у кірковій зоні часточок тимуса не перевищує 49,14 4,25\%, у мозковій - 39,62 $\pm 3,64 \%$, середніх лімфоцитів у кірковій зоні $-3,68 \pm 0,43 \%$, у мозковій $-2,93 \pm$ $0,52 \%$, імунобластів і великих лімфоцитів у кірковій зоні - 0,52 $\pm 0,02 \%$, у мозковій $-0,31 \pm 0,01 \%$.

Другою за кількістю популяцією клітин паренхіми тимуса $\epsilon$ епітеліоретикулоцити, відносна кількість яких поступово зростала паралельно із розвитком інфекційного процесу. Так, за ранньої активної форми PCV2-інфекції відносна кількість епітеліоретикулоцитів у кірковій зоні часточок не перевищувала $12,41 \pm$ $0,82 \%$, а у мозковій $-19,14 \pm 1,26 \%$. За активної форми PCV2-інфекції (хронічна стадія) їх кількість помітно зросла у кірковій зоні до $14,08 \pm 1,72 \%$, у мозковій - до $26,01 \pm 2,34 \%$. У стадію розрішення 
PCV2-інфекції відносна кількість епітеліоретикулоцитів досягала максимальних значень у кірковій зоні часточок $24,02 \pm 1,57 \%$, у мозковій $-30,08 \pm 3,65 \%$.

Значних змін як у кількісних, так і в якісних характеристиках зазнавали i макрофаги. 3 розвитком PCV2-інфекції відносна кількість цих клітин різко збільшувалася, практично в усіх макрофагах виявляли фагоцитований матеріал та збільшені розміри. Відносна кількість макрофагів у тимусі за ранньої активної PCV2-інфекції у кірковій зоні часточок не перевищувала $4,61 \pm 0,11 \%$, у мозковій зоні $4,16 \pm 0,10 \%$, при хронічній $P C V 2$-інфекції (активна стадія) у кірковій зоні часточок збільшилася до $8,15 \pm 0,32 \%$, у мозковій - 7,63 $\pm 0,17 \%$, а при пізній PCV2-інфекції (стадія розрішення) у кірковій зоні часточок сягала $17,06 \pm$ 0,78\%, у мозковій $-19,27 \pm 1,46 \%$.

Серед інших клітин у часточках тимуса переважно траплялися клітини крові, їх відносна кількість суттєво не змінювалася. У кірковій зоні часточок тимуса на ранній активній стадії $P C V 2$-інфекції їх виявляли у мінімальній кількості $2,52 \pm 0,01 \%$, у мозковій дещо більше $-7,11 \pm 0,42 \%$, в активну стадію PCV2інфекції у кірковій зоні часточок їх кількість збільшилася до $6,94 \pm 0,27 \%$, у мозковій до $8,73 \pm 0,63 \%$, а у стадію розрішення, відносна кількість інших клітин не перевищувала $5,58 \pm 0,57 \%$ у кірковій зоні та 7,79 \pm $0,68 \%$ у мозковій зоні часточок тимуса.

За результатами імуногістохімічних досліджень нами встановлено, що експресія антигенних маркерів збудника цирковірусної хвороби незначного та середнього рівня на всіх етапах розвитку клінічно вираженої інфекції виявляється переважно в мононуклеарних фагоцитах, в мозкових зонах часточок і лише в окремих лімфоцитах відповідних зон.

Найбільший рівень експресії антигенних маркерів встановлений в часточках тимуса на пізніх стадіях розвитку $P C V 2$-інфекції. При цьому рівень експресії антигенів збудника $P C V$-2 в мононуклеарних фагоцитах від стадії активної хронічної $P C V 2$-інфекції до стадії пізньої інфекції змінюється несуттєво, а в лімфоцитах, навпаки, помітно зростає.

\section{Висновки}

У тимусі поросят за клінічно вираженої цирковірусної інфекції II типу на різних рівнях структурної організації помітні суттєві морфо-функціональні зміни, вираженість яких має пряму залежність від стадії розвитку інфекційного процесу.

Патоморфологічні зміни в тимусі свиней клінічно хворих на цирковіроз, характеризується поступовим виснаженням лімфоїдної паренхіми з різким зменшенням площі кіркової речовини часточок, що найбільш виражено на останній стадії розвитку інфекційного процесу, тимчасом як на стадії ранньої активної інфекції основні мікроструктурні характеристики тимуса вірогідно не відрізняються від аналогічних показників тимуса контрольних тварин.

На тлі деградації лімфоїдної паренхіми органа тенденцію до збільшення має відносна площа міжчасто- чкової сполучної тканини, вміст якої зростає в 23 рази, а також абсолютні розміри та кількість тимусних тілець, які є індикаторами темпів вікової та акцидентальної інволюції цього органа. Серед клітин лімфоїдної паренхіми часточок найбільш виражено зменшується кількість різних видів лімфоцитів (в 27 разів). При цьому відповідний показник макрофагів та епітеліоретикулоцитів, навпаки, збільшується в 2,5-4 рази.

Перспективи подальших досліджень. Подальші дослідження будуть спрямовані на встановлення особливостей патогістологічних змін селезінки, лімфатичних вузлів поросят на різних стадіях розвитку клінічно вираженої PCV2-інфекції від стадії ранньої активної інфекції до стадії розрішення.

\section{References}

Baimishev, H.B., Shevchenko, B.P., \& Seitov, M.S. (2009). Anatomy of the organs of internal secretion and hemocytopoiesis. Samara: Book.

Gavrilin, P.N., \& Evert, V.V. (2015). Koncepcija mehanizmov povrezhdenija organov immunoj sistemy $u$ svinej pri cirkovirusnoj infekcii (sindrom mul'tisistemnogo istowenija) [The concept of mechanisms of damage to organs of the immune system in pigs with circovirus infection (syndrome of multisystem exhaustion)], Naukovo-tekhnichnyi biuleten NDTs biobezpeky ta ekolohichnoho kontroliu resursiv APK [Science and Technology Bulletin of SRC for Biosafety and Environmental Control of Agroindustrial Complex], 3(2), 12-20 (in Russian).

Gavrilina, O.G., \& Evert, V.V. (2016). Metodychni osoblyvosti zastosuvannia imunohistokhimichnoi diahnostyky tsyrkovirusnoi infektsii svynei [Methodical features of application of immunohistochemical diagnostics of circovirus infection of pigs]. Problems of animal science and veterinary medicine: Veterinary sciences. Collection of scientific works of the Kharkov State Zooveterynary Academy, Kharkov, 32, 294-301 (in Ukrainian).

Goralsky, L.P., Khomich, V.T., \& Kononsky, O.I. (2011). Osnovy histolohichnoi tekhniky i morfofunktsionalni metody doslidzhennia $\mathrm{u}$ normi ta pry patolohii [Basis of histological technology and morphofunctional methods of dosage in normology with pathology]. Zhitomir: Polissya (in Ukrainian).

Krakowka, S., Ellis, J.A., McNeilly, F., Ringler, S., Rings, D.M., \& Allan, G. (2001). Activation of the immune system is the pivotal event in the production of wasting disease in pigs infected with porcine circovirus-2 (PCV-2). Veterinary Pathology, 38, 3142. doi: 10.1354/vp.38-1-31.

Brunborg, I.M., Moldal, T.S., \& Jonassen, C.M. (2004). Quantitation of porcine circovirus type 2 isolated from serum/plasma and tissue samples of healthy pigs and pigs with postweaning multisystemic wasting syndrome using a TaqMan-based real-time PCR. Journal of Virological Methods, 122(2), 171-178. doi: 10.1016/j.jviromet.2004.08.014. 
Nauwynck, H.J., Sanchez, R., Meerts, P. Lefebvre, D.J., Saha, D., Huang, L., \& Misinzo, G. (2012). Cell tropism and entry of porcine circovirus 2 . Virus Research, 164, 43-45. doi: 10.1016/j.virusres.2011.11.003.

McIntosh, K.A., Tumber, A., Harding, J.C., Krakowka, S., Ellis, J.A., \& Hill, J.E. (2009). Development and validation of a SYBR green real-time PCR for the quantification of porcine circovirus type 2 in serum, buffy coat, feces, and multiple tissues. Veterinary Microbiology, 133, 23-33. doi: 10.1016/j.vetmic.2008.06.010.

Doster, A., Subramaniam, S., Yhee, J., Kwon, B., Yu, C., Kwon, S., \& Osorio, F. (2010). Distribution and characterization of IL-10-secreting cells in lymphoid tissues of PCV2-infected pigs. Journal of Veterinary Science, 11, 177-183. doi: 10.4142/jvs.2010.11.3.177.

Dvorak, C.M., Puvanendiran, S., \& Murtaugh, M.P. (2013). Cellular pathogenesis of porcine circovirus type 2 infection. Virus Research, 174, 60-68. doi: 10.1016/j.virusres.2013.03.001.

Lopez-Rodriguez, A., Dewulf, J., Meyns,T. Del-PozoSacristan, R., Andreoni, C., Goubier, A., Chapat, L. et al. (2016). Effect of sow vaccination against porcine circovirus type 2 (PCV2) on virological profiles in herds with or without PCV2 systemic disease. The Canadian Veterinary Journal, 57, 619-628. http://hdl.handle.net/1854/LU-8047986.

Gavrilin, P.N., Gavrilina, E.G., \& Evert, V.V. (2017). Histoarchitectonics of the parenchyma of lymph nodes of mammals with different structure of intranodal lymphatic channel. Ukrainian Journal of Ecology, 7(3), 96-107. doi: 10.15421/2017_54.

Chianini, F., Majo, N., Segales, J. Dominguez, J., \& Domingo, M. (2003). Immunohistochemical characterisation of PCV2 associate lesions in lymphoid and nonlymphoid tissues of pigs 185 with natural postweaning multisystemic wasting syndrome (PMWS). Veterinary Immunology and Immunopathology, 94, 63-75. doi: 10.1016/s0165-2427(03)00079-5.

Opriessnig, T., Meng, X.J., \& Halbur, P.G. (2007). Porcine circovirus type 2-associted disease: Update on current terminology, clinical manifestations, pathogenesis, diagnosis, and intervention strategies. Journal of Veterinary Diagnostic Investigation, 19(6), 591615. doi: 10.1177/104063870701900601. 